\title{
Effect of Motivation, Leadership, and Organizational Culture on Satisfaction and Employee Performance
}

\author{
Maartje PAAIS ${ }^{1}$, Jozef R. PATTIRUHU ${ }^{2}$
}

Received: May 29, 2020 Revised: June 07, 2020 Accepted: July 09, 2020

\begin{abstract}
The study investigates by empirical methods the effect of motivation, leadership, and organizational culture on job satisfaction, and employee performance at Wahana Resources Ltd North Seram District, Central Maluku Regency, Indonesia. This examination intends to be a critical review for academics researching the field of human resources management (HRM). The study's sample consisted of 155 employees who were selected using the Proportionate Stratified Random Sampling method. At the same time, data were collected using a questionnaire and then analyzed using the Structural Equation Modeling on Amos. The results of data analysis showed that work motivation and organizational culture had a positive and significant effect on performance, but did not significantly influence employee job satisfaction. While leadership has a substantial impact on employee job satisfaction, it does not affect performance. The results of testing the coefficient of determination show that job satisfaction is influenced for $57.4 \%$ by motivation, leadership, and culture variables, while employee performance variables are influenced for $73.5 \%$ by motivation, leadership, culture, and job satisfaction variables. Other factors outside this study influence the rest. Motivation, leadership, and organizational culture of employees need to be improved to increase job satisfaction. Invariably, if employee job satisfaction increases, employee performance will also increase.
\end{abstract}

Keywords: Motivation, Leadership, Organization Culture, Work Satisfaction, Employee Performance

JEL Classification Code: M12, M53, M54

\section{Introduction}

Human resources need to be managed professionally to create a balance between the needs of employees, the demands and capabilities of the company's organization, and the importance of quality human resources for the progress of the company (Mappamiring et al., 2020). This balance is the company's primary key to developing

${ }^{1}$ First Author and Corresponding Author. Associate Professor, Department of Management, Faculty of Economics, Universitas Kristen Indonesia Maluku, Ambon, Indonesia [Postal Address: Ot Pattimaipauw Street, Wainitu Nusaniwe, Ambon City, Maluku, Indonesia] Email: maartjepaais80@gmail.com

${ }^{2}$ Associate Professor, Department of Financial Management, Faculty of Economics, Universitas Pattimura, Ambon, Indonesia.

(C) Copyright: The Author(s)

This is an Open Access article distributed under the terms of the Creative Commons Attribution Non-Commercial License (http://Creativecommons.org/licenses/by-nc/4.0/) which permits unrestricted noncommercial use, distribution, and reproduction in any medium, provided the original work is properly cited. productively and achieving the company's goals. Therefore, employees are expected to work productively and professionally. There is the realization that the survival and growth of a company are determined by the strength of money or capital and determined by the success of managing human resources (Arfah \& Aditya, 2019; Nurhilalia et al., 2019; Firman et al., 2020). The management in question is that the company must be able to equate the perceptions or perspectives of employees and leaders to achieve company goals such as through the determination of a right working mentality with high dedication and loyalty to their work, providing guidance, direction, motivation and proper working coordination from a leader to his subordinates. Creating employee job satisfaction is not easy because job satisfaction can only be created if there is continuity between work motivation, leadership, and the organizational culture of the company that can be accommodated well and accepted by all employees. Organizational performance depends on individual performance or, in other words, its production 
will contribute to organizational performance (Akob et al., 2020; Haerani et al., 2020; Nguyen et al., 2019), It means that corporate members' behavior, both individually and in groups, provides power over organizational performance because motivation will affect organizational performance.

Chen et al. (2012) stated that understanding motivation, both existing within employees and from the environment, will help improve performance. In this case, a manager needs to direct motivation by creating an organizational climate through the formation of work culture or corporate culture, so that employees feel encouraged to work harder to achieve a high level of performance. Every employee in work must have hopes or needs, including the need to get rewards, including internal factors such as self-esteem, achievement, as well as external factors such as recognition and attention. The success and performance of a person in a field of work are determined by the level of competence and professionalism in the area occupied, but if the success of the performance without the presence or lack of attention and recognition will affect the decreased motivation, the effect on job satisfaction decreases.

Some previous research (e.g., Thanh et al., 2020; Nguyen et al., 2019; Suong et al., 2019; Yang \& Kim, 2018) show that leadership has a vital effect on organizational activities. Leadership is needed to improve the company's competitiveness on an ongoing basis. Leadership is a process by which a person can become a leader through continuous activities to influence followers to achieve the organization's or company's goals. Besides, the leadership is less sensitive to what is desired by subordinates. Some employees who have never experienced rotation or mutation for a relatively long time have an impact on job satisfaction. Employees who are already in the comfort zone cause a lack of creative ideas and may be lazy to move to other parts of the company. Leadership that is suitable for subordinates will significantly affect their performance, namely, by experiencing job satisfaction for them so that employees carrying out their work will feel more secure and protected.

Another element that is continuously being created in the corporate environment is the organizational culture. Organizational culture is a habit that applies to an organization. Each organization has different patterns and customs. Organizational culture is a set of underlying assumptions and beliefs held by the organization's employees, then developed and passed down to overcome external adaptation and internal integration problems (Limaj \& Bernroider, 2019; Miller, 2006). Therefore, employee dissatisfaction with the organization or company as a whole will have an impact on their dissatisfaction in dealing with their work and will undoubtedly affect their performance. Objectively, this study examines the interrelationship of the variables presented in this section empirically, as illustrated in Figure 1. This study is expected to be a reference for stakeholders and a critical review for academics in the HRM field.

\section{Literature Review and Hypotheses Development}

Motivation is crucial for employees so that the work that has been charged can be carried out, as it should be per the company's operational standards. Motivation is the power that allows someone to act in the direction of a particular goal (Indahingwati et al., 2019). This motivation is like determining outcomes such as productivity, performance, and perseverance. Arshadia (2010), in his study, confirmed a positive influence between motivation and performance. Motivation is the existence of autonomy support, which means that organizational managers pay attention to every decision that is meant to lead to the welfare of employees. Besides, there are reasonable regulations in covering flexible work needs. Motivation is fundamental in organizations such as the competence of workers themselves and relational relationships (Arshadia, 2010; Van den Berghe et al., 2014). Some of the recent studies are summarized as a foundation for critical thinking in this study, which is illustrated in Appendix 1.

Motivated employees are more oriented towards autonomy and freedom and are more self-motivated compared to less motivated employees, which causes development opportunities to benefit them (Demircioglu \& Chen, 2019; Arshadia, 2010). Employee motivation can be categorized as intrinsic and extrinsic (Demircioglu \& Chen, 2019; Hayati \& Caniago, 2012). Research by Hayati and Caniago (2012) that focused on the role of intrinsic motivation influencing satisfaction, organizational commitment, and performance in the perspective of Islamic work ethics, found that the Islamic work ethic has a more significant effect on intrinsic motivation and organizational commitment than their impact on job satisfaction and job performance. Intrinsic motivation is related to satisfaction with oneself, which can be reflected by achievement, recognition, acceleration, work itself, responsibilities, and personal growth. Extrinsic motivation arises when there are triggering factors from outside the employee's self, such as security, work conditions, company policy, status, compensation, and interpersonal relationships (Mitchell, Schuster, \& Jin, 2020; Van den Berghe et al., 2014).

Marinak and Gambrell (2008) said that motivation is a psychological process that provides goals and direction for employee behavior or as an internal drive to meet employee satisfaction as well as internal processes and external forces related to organizational behavior. Employee job satisfaction is a collage that bridges between the role of reward for work involvement (Brown, 2014), so it can be said that engagement 
antecedents comes from feeling satisfied at work. In career matters, an employee's preference for their career is based on whether the job they have inspires them (Chawla et al., 2017). Work is not always tangible as an activity to find money for my desires and needs in life, but further than that the role of the profession and one's career must also provide extraordinary inspiration in life (Hulkko-Nyman et al., 2012; Akob et al., 2020; Thanh et al., 2020). However, opinions about causality are firmly demonstrated by several studies about reward and engagement that are inversely proportional, where one study entitled Multigenerational Differences in Career Preferences, Reward Preferences, and Work Engagement, which analyzes in-depth about career preferences, rewards and engagement in India found that results were not significant (Chawla et al., 2017). Chawla, Dokadia, and Rai (2017) emphasize that reward is only a means of determining someone's motivation at work, but not as the main reason an employee wants to stay in their organization. Based on prior research, it can be assumed that the hypothesis is:

H1: Motivation has a positive and significant effect on job satisfaction.

H2: Motivation has a positive and significant effect on performance.

H7: Job satisfaction has a positive and significant effect on performance.

Leadership theory and organizational theory become essential instruments in carrying out activities in organizations (Stogdill, 1974). Leadership in the organization needs to be owned by all internal members of the organization, regardless of its vision and mission. Therefore, an organization or company needs a leader figure that can be an example for other internal members of the organization. Leadership is a process to influence existing activities, primarily to conduct organizations in groups to achieve goals set from the beginning (Mitchell \& Scott, 1987). For Pigors, in his book "Leadership and Domination," leadership is an encouraging process that controls the human usability in pursuing shared goals, through successful interaction of various individual differences (Pigors, 1933). Organizational theory is a collection of knowledge that deals with the mechanism of cooperation of more than one person systematically to achieve predetermined goals (Lewis \& Abdul-Hamid, 2006). In its history records, the theory of the organization up to the modern age has been quite rapid. The organization's classic approach defines the organization as the relationship structure, power, purpose, and role, as well as the communication involved in cooperation (Schwartz, 2018). The delegation of tasks that are centralized, specialized, and structural, rigid and do not contain creativity is striking in classical organizational theory (Lamond, 2003; Spender \& Kijne, 2012). The concept of neo-classical organizational theory emphasizes the psychological and social aspects of employees as part of workgroups. What stands out in neo-classical organizational theory is the emphasis on the participation point of each internal member of the organization in decision-making, job enlargement, and the opportunity for junior members to participate in top management decision making (Guillén, 1994). Furthermore, the organizational theory then develops towards a more modern organizational theory that states that all elements in the organization are interdependent, unified. The emphasis on closed classical and neo-classic methods shifts to the concept of a recent regulatory approach that considers that achieving organizational goals requires that corporate systems must be open to create a stable and transparent work environment (Katz \& Kahn, 1978).

Several researchers (i.e., Kammerhoff, Lauenstein, \& Schütz, 2019; Eliyana, Ma'arif, \& Muzakki, 2019; (Meng \& Berger, 2019) states that there is a strong correlation between the role of leadership on job satisfaction and employee performance. Chiniara and Bentein (2016) focus on how the relationship between leadership and individual performance is mediated between competence and satisfaction based on Self Determination theory and OCB (Organizational Citizenship Behavior). Structural equation modeling results indicate that leadership strongly predicts all three needs' satisfaction - autonomy needs satisfaction-mediated servant leadership's effect on task performance, OCB as an organization, and individually correlate with achievement, and leadership in the organization. In line with what has been stated by Braun, Peus, Weisweiler, and Frey (2013), focus is on analyzing the relations between transformational leadership, trust in supervisors and teams, job satisfaction, and team performance multilevel analysis. Reinforcing several other studies, transformational leadership was positively related to followers' job satisfaction at an individual as well as team levels of analysis and objective team performance. The relationship between individual perceptions of supervisors' transformational leadership and job satisfaction was mediated by trust in the supervisor and confidence in the team. Based on prior research, it can be assumed that the hypothesis is:

H3: Leadership has a positive and significant effect on job satisfaction

H4: Leadership has a positive and significant effect on performance

The studies by Meng and Berger (2019) examine the impact of critical organizational factors (organizational culture and excellent leader performance) on public relations professionals' overall job satisfaction, focusing on testing 
the common mediating effects work. They confirmed the influential impact corporate culture and leader performance could have on public relations professionals' work engagement, trust, and job satisfaction. More importantly, results revealed the significant joint mediating effects of commitment and trust on professionals' job satisfaction, when supportive organizational culture and excellent leader performance were achieved. Corporate culture, in essence, has good value for the progress of an organization. Organizational culture includes broader and more profound aspects and, thus, becomes a basis for creating an ideal organizational climate. Recently, the problem of corporate culture has become a real concern, especially attractive in uncertain working conditions (Meng \& Berger, 2019; Stone, Stone-Romero, \& Lukaszewski, 2007). Culture is the total thoughts, works, and results of human actions, which are not rooted in their instincts, and therefore can only be triggered by humans after going through a learning process. Culture is the essence of what is essential in organizations. The activities of member commands and prohibitions describe something that is done and not done that regulates the behavior of members. So, culture contains what may or may not be done so that it can be stated as a guideline used to carry out organizational activities.

Silla, Navajas, and Koves (2017) examine the relationship between corporate reliability and culture organization on job satisfaction. They found that employee communication satisfaction partially mediated the positive relationships between a constructive culture and a safety-conscious work environment. Apart from that, many relevant studies also explain that the mediation of organizational justice as part of the corporate culture element plays a vital role in increasing job satisfaction and employee performance (e.g., Kim \& Chung, 2019; Dong \& Phuong, 2018; Islam, Bangish, Muhammad, \& Jehan, 2016). Haerani et al. (2020) analyze the effect of structural Person-Organization Fit and organizational justice on organizational commitment, job satisfaction, Organizational Citizenship Behavior, and employee performance. When compared between personorganization Fit and Organizational Justice, it is found that organizational justice has a more critical role in building Human Resource performance compared to PersonOrganization Fit because organizational truth is better able to provide job satisfaction and make organizational commitment, and OCB as a prerequisite for its formation to better Human Resources performance. Therefore, based on prior research, it can be assumed that the hypothesis is:

H5: Organizational culture has a positive and significant effect on job satisfaction

H6: Organizational culture has a positive and significant effect on performance

\section{Research Methods and Materials}

\subsection{Samples}

Subjects of the research were all employees of Wahana Resources Ltd, North Seram District, Central Maluku Regency, Indonesia, totalling 430 people consisting of 244 permanent employees and 186 non-permanent employees. The research period is from April to December 2019

\subsection{Materials and Measurement}

The measurement value equalization model requires several stages, such as variable investment and government expenditure, namely, data transformation using SPSS's Log10 compute variable. The next step is testing the normality using the asymptotic/Kolomogorv-Smirnov method to determine the correlation test, using the Pearson correlation method. After transforming the value variable, the trial is continued by testing the hypotheses through the correlation testing method with significance $(\mathrm{p}<0.05)$. The secondary data sample of the study is illustrated in Appendix 1.

Illustrations of recapitulation of the minimum wage variable data are calculated based on the average value of 34 provinces in Indonesia. Variable bank credit (i.e., average credit from the instruments of agriculture, hunting, fisheries, mining and quarrying, processing industry, gas and water electricity, construction, wholesale and retail trade, provision of accommodation and provision of food and beverages, transportation, warehousing and communication, financial intermediaries, real estate, rental business, and company services, government administration, defense and compulsory social security, educational facilities, health services, and social activities, community services, social culture, entertainment, and other individuals, individual services were serving households, international agencies and other international extra bodies, events which have unclear boundaries). The average variable of government expenditure is based on function (i.e., public services, defense, order and security, economy, environment, housing and public facilities, health, tourism and culture, religion, education, social protection). Complete economic growth variable and employment variable data are in Appendix 2.

\section{Results and Discussion}

\subsection{Statistical Results}

Appendix 3 shows the validity of the research variables explained by looking at the value of the Critical Ratio (CR) and the estimated value, then compares it with the Standard error value that is attempted small. The measurement of CFA 
on the regression weight of the most dominant motivational variable was item $\mathrm{X} 1.5$ (Estimate $=1.088 ; \mathrm{SE}=0.121 ; \mathrm{CR}=$ 9.002; Sig <0.01). Leadership variables The most dominant items composing leadership variables are item X21 (estimate $=1,203 ; \mathrm{SE}=0.169 ; \mathrm{CR}=7.136 ; \mathrm{sig}<0.01)$. The most dominant item cultural variable is $\mathrm{X} 32$ (Estimate $=0.938$; $\mathrm{SE}=0.106 ; \mathrm{CR}=8.858 ; \mathrm{Sig}<0.01)$. Then, in endogenous variables such as satisfaction variables, the most dominant items are Y15 (Estimate $=1,029 ; \mathrm{SE}=0.090 ; \mathrm{CR}=11,450$; sig <0.01) and items Y23 (Estimate $=1,210 ; \mathrm{SE}=0.108$; $\mathrm{CR}=11,237$; Sig $<0.01$ ) on the Performance variable. Overall the measurement of the validity and reliability of the variables is declared valid and reliable. Furthermore, in the measurement of the feasibility of the model, modification of the model is done by connecting with lines or covariate between error variables in the model, according to those recommended by AMOS (see Figure 2). In the feasibility test of the first stage of the model, several standard assumption tests do not meet the criteria. After testing the second stage through modification indices, the measurement of the feasibility of the model has been declared feasible.

Testing the hypotheses, as illustrated in Appendix 4, reveals that, of the seven hypotheses of the study, two hypotheses (H5 and H6) are not appropriate. Both of these hypotheses, with the significance value of $<0.05$, have adverse or indirect effects.

\subsection{Discussion}

Motivation as a trigger in increasing work satisfaction and quality has a significant psychological impact on a company's strategy in various business operations. Giving a generous bonus in every work measurement result is a form of company professionalism. Besides, every employee

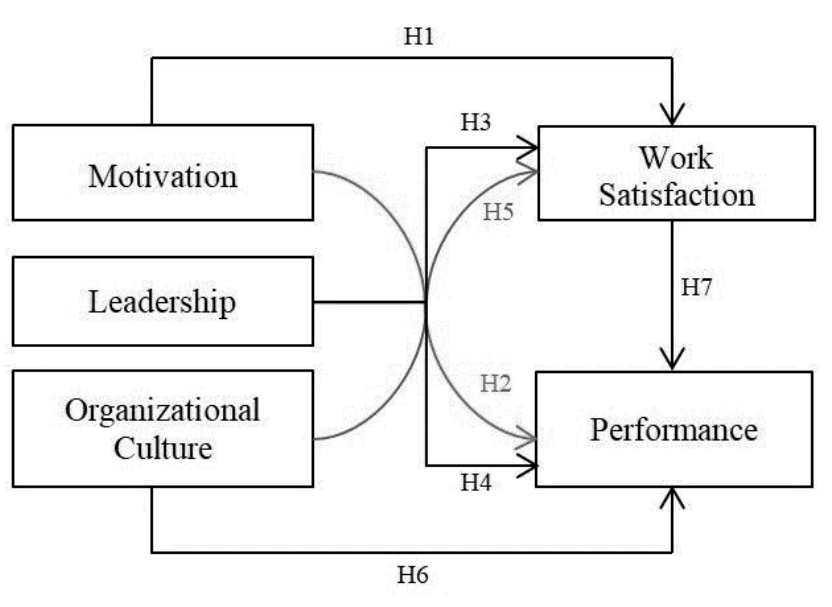

Figure 1: Conceptual Framework always awaits career paths wherever they work, but focusing on bonuses and high salaries do not always provide optimal results on satisfaction and performance. Career paths that are considered reasonable by the company provide evidence that this is the most important motivation for an employee to remain in the company. The organizational environment and social relations at work also become the main reason employees are satisfied or unsatisfied. A precise, measured, and planned training and reward system. This study also shows that leadership has a positive and significant effect on employee satisfaction and performance. This can be interpreted that leadership factors become essential and necessary for organizations to realize job satisfaction. Leadership means having the ability to direct, mobilize, and influence employees to continually improve job satisfaction in carrying out their main tasks and functions in the work process.

The fact shows that leadership in the form of leadership type in the way of leading personally, non-personal, democratic, authoritarian, paternalistic, and talent is needed by organizations to increase job satisfaction in their organizations. Leaders in applying the leadership type often change the nature of leadership under the conditions of employees and the dynamics of the organization faced. The appropriateness of results and facts between previous research and the results of this study can be explained per indicator of the type of leadership in increasing employee job satisfaction. First, the kind of leadership seen from the personality shown is a manager who has an interest in various employee activities. Managers have characters that are close to employees in delivering orders, mandates, or considerations relating to employees' matters in increasing work satisfaction factors. Managers always hold discussions

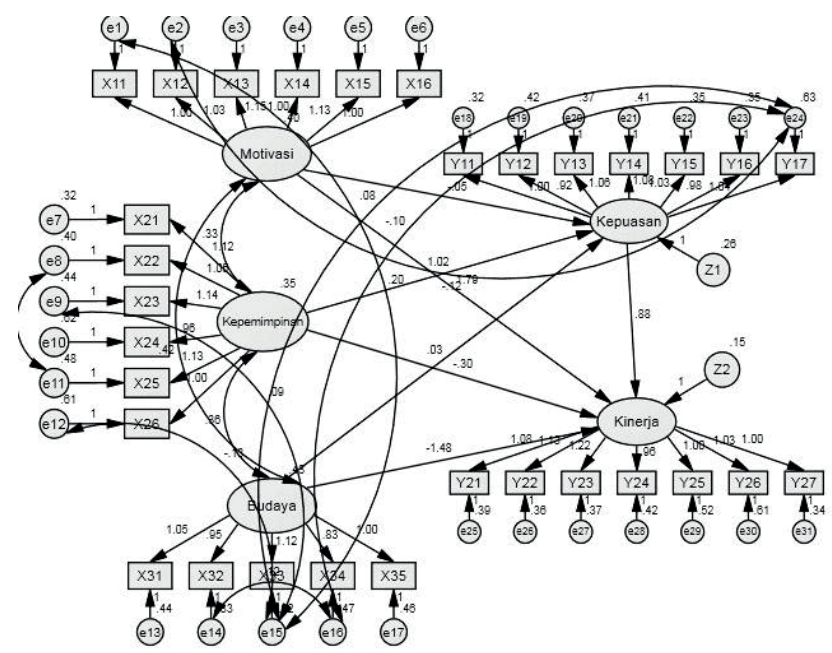

Figure 2: Modification Indices 
with employees about various issues relating to work activities that aim so that employees can continue to improve job satisfaction in the company. Knowing the character of employees is so essential that the application of leadership patterns can be appropriate. Indeed, the leadership pattern is based on the type of organizational nature, organizational culture, job-based employment, and the level of internal organizational knowledge.

\section{Conclusions}

This study has demonstrated that several dependent variables have a vital role in influencing job performance and satisfaction. This study has also added empirical considerations in management scholarship about the aspect of leadership motivation and its beneficial effect on organizations. In many studies on human resource management theory, employees are valuable assets that must be maintained by companies or organizations because they are the spearhead of the production process. This study also enriches the results of previous studies that are relevant to this case study. The composition of motivation as a driving factor in improving employee performance and satisfaction is inseparable from the role of leadership to change the organizational atmosphere to be more optimal and professional.

\section{References}

Akob, M., Arianty, R., \& Putra, A. H. P. K. (2020). The mediating role of distribution Kahns engagement: An empirical evidence of salesforce in Indonesia. Journal of Asian Finance, Economics and Business, 7(2), 249-260. https://doi.org/10.13106/ jafeb.2020.vol7.no2.249

Arfah, A., \& Aditya, H. P. K. P. (2019). Analysis of Productivity and Distribution of Female Workers in FB's Industries. Journal of Distribution Science, 17(3), 31-39. https://doi.org/10.15722/ jds.17.03.201903.31

Arshadia, N. (2010). Necessary need satisfaction, work motivation, and job performance in an industrial company in Iran. Procedia - Social and Behavioral Sciences, 5(January), 1267-1272. https://doi.org/10.1016/j.sbspro.2010.07.273

Braun, S., Peus, C., Weisweiler, S., \& Frey, D. (2013). Transformational leadership, job satisfaction, and team performance: A multilevel mediation model of trust. Leadership Quarterly, 24(1), 270-283. https://doi.org/10.1016/j. leaqua.2012.11.006

Brown, D. (2014). The Future of Reward Management. Compensation \& Benefits Review, 46(3), 147-151. https://doi. org/10.1177/0886368714549303

Chawla, D., Dokadia, A., \& Rai, S. (2017). Multigenerational Differences in Career Preferences, Reward Preferences and Work
Engagement among Indian Employees. Global Business Review, 18(1), 181-197. https://doi.org/10.1177/0972150916666964

Chen, Y.-Y., Park, J., \& Park, A. (2012). Existence, relatedness, or growth? Examining the turnover intention of public child welfare caseworkers from a human needs approach. Children and Youth Services Review, 34(10), 2088-2093. https://doi.org/ https://doi.org/10.1016/j.childyouth.2012.07.002

Chiniara, M., \& Bentein, K. (2016). Linking servant leadership to individual performance: Differentiating the mediating role of autonomy, competence and relatedness need satisfaction. Leadership Quarterly, 27(1), 124-141. https://doi.org/10.1016/j. leaqua.2015.08.004

Demircioglu, M. A., \& Chen, C. A. (2019). Public employees' use of social media: Its impact on need satisfaction and intrinsic work motivation. Government Information Quarterly, 36(1), 51-60. https://doi.org/10.1016/j.giq.2018.11.008

Dong, L. N. T., \& Phuong, N. N. D. (2018). Organizational justice, job satisfaction and organizational citizenship behavior in higher education institutions: A research proposition in Vietnam. Journal of Asian Finance, Economics and Business, 5(3), 113119. https://doi.org/10.13106/jafeb.2018.vol5.no3.113

Eliyana, A., Ma'arif, S., \& Muzakki. (2019). Job satisfaction and organizational commitment effect in the transformational leadership towards employee performance. European Research on Management and Business Economics, 25(3), 144-150. https://doi.org/10.1016/j.iedeen.2019.05.001

Firman, A., Mustapa, Z., Ilyas, G. B., \& Putra, A. H. P. K. (2020). Relationship of TQM on managerial perfomance: Evidence from property sector in Indonesia. Journal of Distribution Science, 18(1), 47-57. https://doi.org/10.15722/jds.18.01.20201.47

Guillén, M. F. (1994). Models of management: Work, authority, and organization in a comparative perspective. 1-432. University of Chicago Press.

Haerani, S., Sumardi, Hakim, W., Hartini, \& Putra, A. H. P. K. (2020). Structural Model of Developing Human Resources Performance: Empirical Study of Indonesia States Owned Enterprises. Journal of Asian Finance, Economics and Business, 7(3), 211-221. https://doi.org/10.13106/jafeb.2020. vol7.no3.211

Hayati, K., \& Caniago, I. (2012). Islamic Work Ethic: The Role of Intrinsic Motivation, Job Satisfaction, Organizational Commitment and Job Performance. Procedia - Social and Behavioral Sciences, 65(December), 272-277. https://doi. org/10.1016/j.sbspro.2012.11.122

Hulkko-Nyman, K., Sarti, D., Hakonen, A., \& Sweins, C. (2012). Total rewards perceptions and work engagement in eldercare organizations. International Studies of Management and Organization, 42(1), 24-49. https://doi.org/10.2753/IMO00208825420102

Indahingwati, A., Launtu, A., Tamsah, H., Firman, A., Putra, A. H. P. K., \& Aswari, A. (2019). How Digital Technology Driven Millennial Consumer Behaviour in Indonesia. Journal of Distribution Science, 17(8), 25-34. http://dx.doi.org/10.15722/ jds.17.08.201908.25 
Islam, Z. ul, Bangish, S. B., Muhammad, H., \& Jehan, A. S. (2016). The Impact of HR Practices on Job satisfaction: A Case Study of Hotel Industry in Pakistan. Journal of Asian Finance, Economics and Business, 3(1), 43-48. https://doi.org/10.13106/ jafeb.2016.vol3.no1.43.

Kammerhoff, J., Lauenstein, O., \& Schütz,A.(2019). Leading toward harmony - Different types of conflict mediate how followers' perceptions of transformational leadership are related to job satisfaction and performance. European Management Journal, 37(2), 210-221. https://doi.org/10.1016/j.emj.2018.06.003

Katz, D., \& Kahn, R. L. (1978). The social psychology of organizations (Vol. 2). New York, NY: Wiley.

Kim, S. J., \& Chung, E. K. (2019). The effect of organizational justice as perceived by occupational drivers on traffic accidents: Mediating effects of job satisfaction. Journal of Safety Research, 68(February), 27-32. https://doi.org/10.1016/j.jsr.2018.11.001

Lamond, D. (2003). Henry Mintzberg vs Henri Fayol: of lighthouses, cubists and the emperor's new clothes. Journal of Applied Management and Entrepreneurship, 8(4), 5-23.

Lewis, C. C., \& Abdul-Hamid, H. (2006). Implementing effective online teaching practices: Voices of exemplary faculty. Innovative Higher Education, 31(2), 83-98. https://doi. org/10.1007/s10755-006-9010-Z

Limaj, E., \& Bernroider, E. W. N. (2019). The roles of absorptive capacity and cultural balance for exploratory and exploitative innovation in SMEs. Journal of Business Research, 94(September), 137-153. https://doi.org/10.1016/j. jbusres.2017.10.052

Mappamiring, M., Akob, M., \& Putra, A. H. P. K. (2020). What Millennial Workers Want? Turnover or Intention to Stay in Company. Journal of Asian Finance, Economics and Business, 7(5), 237-248. https://doi.org/10.13106/jafeb.2020.vol7. no5.237

Marinak, B. A., \& Gambrell, L. B. (2008). Intrinsic motivation and rewards: What sustains young children's engagement with text? Literacy Research and Instruction, 47(1), 9-26. https:// doi.org/10.1080/19388070701749546

Meng, J., \& Berger, B. K. (2019). The impact of organizational culture and leadership performance on PR professionals' job satisfaction: Testing the joint mediating effects of engagement and trust. Public Relations Review, 45(1), 64-75. https://doi. org/10.1016/j.pubrev.2018.11.002

Miller, D. (2006). Strategic human resource management in department stores: An historical perspective. Journal of Retailing and Consumer Services, 13(2), 99-109. https://doi. org/10.1016/j.jretconser.2005.08.012

Mitchell, R., Schuster, L., \& Jin, H. S. (2020). Gamification and the impact of extrinsic motivation on needs satisfaction: Making work fun?. Journal of Business Research, 106(November), 323-330. https://doi.org/10.1016/j.jbusres.2018.11.022

Mitchell, T. R., \& Scott, W. G. (1987). Leadership failures, the distrusting public, and prospects of the administrative state. Public Administration Review, 47(6), 445-452.
Nguyen, H. M., Mai, L. T., \& Huynh, T. L. (2019). The Role of Transformational Leadership toward Work Performance through Intrinsic Motivation: A Study in the Pharmaceutical Field in Vietnam. Journal of Asian Finance, Economics and Business, 6(4), 201-212. https://doi.org/10.13106/jafeb.2019. vol6.no4.201

Nurhilalia, Rahman Kadir, A., Mahlia, M., Jusni, \& Aditya, H. P. K. P. (2019). Determinant of market orientation on SME performance: RBV and SCP perspective. Journal of Distribution Science, 17(9). 35-45. https://doi.org/10.15722/ jds.17.09.201909.35

Pigors, P. (1933). Leadership and domination among children, 140-157. Houghton Mifflin Company

Schwartz, H. S. (2018). Organization in the age of hysteria. In: Society against Itself (pp. 163-189). London, UK: Routledge.

Silla, I., Navajas, J., \& Koves, G. K. (2017). Organizational culture and a safety-conscious work environment: The mediating role of employee communication satisfaction. Journal of Safety Research, 61(June), 121-127. https://doi.org/10.1016/j. jsr.2017.02.005

Spender, J.-C., \& Kijne, H. (2012). Scientific Management: Frederick Winslow Taylor's Gift to the World?. Berlin Heidelberg, Germany: Springer Science \& Business Media.

Stogdill, R. M. (1974). Handbook of leadership: A survey of theory and research. New York, NY: Free Press.

Stone, D. L., Stone-Romero, E. F., \& Lukaszewski, K. M. (2007). The impact of cultural values on the acceptance and effectiveness of human resource management policies and practices. Human Resource Management Review, 17(2), 152-165. https://doi.org/10.1016/j.hrmr.2007.04.003

Suong, H. T. T., Thanh, D. D., \& Dao, T. T. X. (2019). The Impact of Leadership Styles on the Engagement of Cadres, Lecturers and Staff at Public Universities - Evidence from Vietnam. Journal of Asian Finance, Economics and Business, 6(1), 273280. http://doi.org/10.13106/jafeb.2019.vol6.no1.273

Thanh, T., Doan, T., Cam, L., Nguyen, T., Dan, T., \& Nguyen, N. (2020). Emotional Intelligence and Project Success. The Roles of Transformational Leadership and Organizational Commitment. 7(3), 223-233. https://doi.org/10.13106/ jafeb.2020.vol7.no3.223

Van den Berghe, L., Soenens, B., Aelterman, N., Cardon, G., Tallir, I. B., \& Haerens, L. (2014). Within-person profiles of teachers' motivation to teach: Associations with need satisfaction at work, need-supportive teaching, and burnout. Psychology of Sport and Exercise, 15(4), 407-417. https://doi.org/10.1016/j. psychsport.2014.04.001

Yang, H.-C., \& Kim, Y.-E. (2018). The Effects of Corporate Social Responsibility on Job Performance: Moderating Effects of Authentic Leadership and Meaningfulness of Work. Journal of Asian Finance, Economics and Business, 5(3), 121-132. http:// doi.org/10.13106/jafeb.2018.vol5.no3.121 
Appendix 1: Resume of Prior Research

\begin{tabular}{|c|c|}
\hline Author & Result \\
\hline Arshadia, 2010 & $\begin{array}{l}\text { All variables have a positive and significant effect on work } \\
\text { performance and motivation. Autonomy support means that } \\
\text { managers pay attention to pro-worker decision making; have } \\
\text { reasonable regulations in covering work needs, supportive } \\
\text { and flexible organizations. Motivation is fundamental in } \\
\text { organizations such as the competence of workers themselves } \\
\text { and relational relationships. }\end{array}$ \\
\hline Demircioglu \& Chen, 2019 & $\begin{array}{l}\text { employees' use of social media is positively related to } \\
\text { employees' need satisfaction (autonomy, relatedness, and } \\
\text { competence) and, accordingly, intrinsic work motivation }\end{array}$ \\
\hline Hayati \& Caniago, 2012 & $\begin{array}{l}\text { the Islamic work ethic more significant effect on intrinsic } \\
\text { motivation and organizational commitment than their impact on } \\
\text { job satisfaction and job performance. }\end{array}$ \\
\hline Mitchell, Schuster, \& Jin, 2020 & $\begin{array}{l}\text { extrinsic motivation can decrease employees' autonomy, and } \\
\text { competence needs satisfaction. Still, when extrinsic motivation } \\
\text { is internalized (such as through perceived personal value), } \\
\text { it can support needs satisfaction, intrinsic motivation, and } \\
\text { behavioral intention. }\end{array}$ \\
\hline Kammerhoff, Lauenstein, \& Schütz, 2019 & $\begin{array}{l}\text { The conflict has adverse effects on employees' job satisfaction } \\
\text { and performance. On the other hand, transformational } \\
\text { leadership has been shown to have strong positive relations } \\
\text { with job satisfaction and performance but is negatively related } \\
\text { to workplace conflicts. }\end{array}$ \\
\hline Eliyana, Ma'arif, \& Muzakki, 2019 & $\begin{array}{l}\text { This study found that transformational leadership has a } \\
\text { significant direct effect on job satisfaction and organizational } \\
\text { commitment. Transformational leadership cannot have a } \\
\text { significant impact on work performance when it is intervened } \\
\text { by organizational commitment and cannot directly impact work } \\
\text { performance }\end{array}$ \\
\hline Meng \& Berger, 2019 & $\begin{array}{l}\text { More importantly, results revealed the significant joint } \\
\text { mediating effects of engagement and trust on professionals' } \\
\text { job satisfaction, when supportive organizational culture and } \\
\text { excellent leader performance were achieved. The study } \\
\text { concludes with research and practical implications. }\end{array}$ \\
\hline Chiniara \& Bentein, 2016 & $\begin{array}{l}\text { Structural equation modeling results indicate that servant } \\
\text { leadership strongly predicted all three needs' satisfaction; } \\
\text { autonomy need satisfaction mediated servant leadership's } \\
\text { effect on task performance, OCB-Individual (OCB-I) and } \\
\text { OCB-Organization (OCB-O); competence need satisfaction } \\
\text { mediated servant leadership's effect on task performance } \\
\text { only; and relatedness need satisfaction mediated servant } \\
\text { leadership's effect on both OCB-I and OCB-O. }\end{array}$ \\
\hline Braun, Peus, Weisweiler, \& Frey, 2013 & $\begin{array}{l}\text { Transformational leadership was positively related to followers' } \\
\text { job satisfaction at an individual as well as team levels of } \\
\text { analysis and objective team performance. The relation } \\
\text { between individual perceptions of supervisors' transformational } \\
\text { leadership and job satisfaction was mediated by trust in the } \\
\text { supervisor as well as trust in the team. }\end{array}$ \\
\hline
\end{tabular}




\begin{tabular}{|c|c|}
\hline Author & Result \\
\hline Silla, Navajas, \& Koves, 2017 & $\begin{array}{l}\text { Employee communication satisfaction partially mediated the } \\
\text { positive relationships between a constructive culture and a } \\
\text { safety-conscious work environment }\end{array}$ \\
\hline Kim \& Chung, 2019 & $\begin{array}{l}\text { The analysis shows that the mediation model is statistically } \\
\text { significant. That is, drivers with a lower level of perceived } \\
\text { organizational justice showed a higher frequency of traffic } \\
\text { accidents, and the mediating effect of job satisfaction was also } \\
\text { significant }\end{array}$ \\
\hline Dong \& Phuong, 2018 & $\begin{array}{l}\text { organizational citizenship behavior is one of the most critical } \\
\text { factors that influence organizational performance. }\end{array}$ \\
\hline Islam, Bangish, Muhammad, \& Jehan, 2016 & $\begin{array}{l}\text { There is a significant relationship between HR practices } \\
\text { and job satisfaction. Moreover, Recruitment and selection, } \\
\text { empowerment, and working conditions have a positive effect } \\
\text { on job satisfaction. In contrast, compensation harms job } \\
\text { satisfaction, which indicates that most employees are not } \\
\text { satisfied with the employer's payment. Empirical findings } \\
\text { concluded that best HR practices have a significant and } \\
\text { positive effect on employees' job satisfaction. }\end{array}$ \\
\hline Haerani, Sumardi, Hakim, Hartini, \& Putra, 2020 & $\begin{array}{l}\text { When compared between person-organization Fit and } \\
\text { Organizational Justice, it is found that organizational } \\
\text { justice has a more critical role in building Human Resource } \\
\text { performance compared to Person-Organization Fit, because } \\
\text { organizational justice is better able to provide job satisfaction } \\
\text { and make organizational commitment and OCB as a } \\
\text { prerequisite for its formation to better Human Resources } \\
\text { performance }\end{array}$ \\
\hline Akob, Arianty, \& Putra, 2020 & $\begin{array}{l}\text { The results of this study indicate that the work-life balance } \\
\text { program positively influences engagement. Overall, we can } \\
\text { conclude that commitment not only serves as a means for } \\
\text { employees to fulfill formal job requirements. }\end{array}$ \\
\hline Thanh et al., 2020 & $\begin{array}{l}\text { The result shows that emotional intelligence and } \\
\text { transformational leadership making the project even } \\
\text { more successful as the mediation actor. Furthermore, the } \\
\text { project commitment also has the moderator effect between } \\
\text { transformational leadership and project success. With the } \\
\text { result of the study, project managers should be aware of the } \\
\text { importance of emotional intelligence and their commitment to } \\
\text { the ability to manage projects successfully. }\end{array}$ \\
\hline
\end{tabular}


Appendix 2: Measurement of Variable

\begin{tabular}{|c|c|}
\hline Variables & Item Code \\
\hline Motivation & $\begin{array}{l}\text { - } \mathrm{X} 1.1=\mathrm{I} \text { receive a fair bonus for every work measurement } \\
\text { - } \mathrm{X} 1.2=\mathrm{I} \text { believe there is attention to the career path of employees } \\
\text { - } \mathrm{X} 1.3=\mathrm{I} \text { think the care given by the organization to family needs can be met } \\
\text { - } \mathrm{X} 1.4=\mathrm{I} \text { receive proper treatment in an organizational environment (friendship and relationship) } \\
\text { between people in the organization is very good and professionally turned out } \\
\text { - } \mathrm{X} 1.5=\text { Fair company rules in providing rewards and punishment } \\
\text { - } \mathrm{X} 1.6 \text { = There is regular training for internal organizations }\end{array}$ \\
\hline Leadership & $\begin{array}{l}\text { - X2.1 = I feel that the direction of the place where I work has the responsibility and is reliable } \\
\text { - X2.2 = My leader is always inviting employee discussions, especially matters relating to the } \\
\text { level of employee welfare } \\
\text { - X2.3 = Our leader is a fair person } \\
\text { - X2.4 = Our leader understands employees professionally; he can distinguish personal and } \\
\text { professional matters } \\
\text { - X2.5 = Our leaders give us confidence in doing work processes creatively as long as they do } \\
\text { not violate company regulations } \\
\text { X2.6 = Our leaders always think about the company and the interests of employees }\end{array}$ \\
\hline Organizational Culture & $\begin{array}{l}\text { - X3.1 = Vision and mission of the company are always carried out well by the organization and } \\
\text { obeyed by all company elements of the company } \\
\text { - X3.2 = There is trust in the leadership } \\
\text { - X3.3 = There is a fair, equitable and professional division of work } \\
\text { - X3.5 = A conducive and homely work environment }\end{array}$ \\
\hline Work Satisfaction & $\begin{array}{l}\text { - } \mathrm{Y} 1.1=\text { There is a balance between work quality and social quality of life } \\
\text { - Y1.2 = There is a feeling of pride working in this company } \\
\text { - } \mathrm{Y} 1.3=\text { I feel motivated to continue working actively and optimally } \\
\text { - } \mathrm{Y} 1.4=\text { Organization and elements of the organization inspire me and those around me } \\
\text { - Y1.5 = There is satisfaction in working with colleagues and teams in this organization } \\
\text { - Y1.6 = All of our suggestions and complaints as employees are listened to and considered by } \\
\text { the company } \\
\text { - Y1.7 = Management shows enthusiasm for the employee's career }\end{array}$ \\
\hline Performance & $\begin{array}{l}\text { - Y2.1 = There are strict rules that make employees must comply with the regulations } \\
\text { - Y2.2 = There is a professional system reward so that all forms of assessment are carried out } \\
\text { transparently } \\
\text { - Y2.3 = The company continues to increase rewards and bonuses for employees who have } \\
\text { achieved company targets } \\
\text { - Y2.4 = Training \& Development motivates employees to work optimally } \\
\text { - Y2.5 = Lack of absenteeism and absenteeism during this time } \\
\text { - Y2.6 = The goal given by the company is always achieved or even exceeds } \\
\text { - Y2.7 = An increase in the value of assets and good corporate investment is reflected through } \\
\text { the results of the company's financial statements that profit. }\end{array}$ \\
\hline
\end{tabular}


Appendix 3: Confirmatory Factor Analysis (CFA) and Goodness of Fit Model

\begin{tabular}{|c|c|c|c|c|c|c|c|}
\hline Item & Variables & Reliability & Estimate & S.E. & C.R. & P-Value & Result \\
\hline X11 & Motivation & .661 & 1.000 & & & & \\
\hline $\mathrm{X} 12$ & Motivation & .727 & 1.011 & .124 & 8.183 & $* * *$ & Valid \\
\hline $\mathrm{X} 13$ & Motivation & .776 & 1.107 & .126 & 8.789 & $* * *$ & Valid \\
\hline $\mathrm{X} 14$ & Motivation & .705 & .969 & .119 & 8.136 & $* * *$ & Valid \\
\hline X15 & Motivation & .799 & 1.088 & .121 & 9.002 & $* * *$ & Valid \\
\hline X16 & Motivation & .658 & .967 & .127 & 7.642 & $* * *$ & Valid \\
\hline $\mathrm{X} 26$ & Leadership & .607 & 1.000 & & & & \\
\hline $\mathrm{X} 25$ & Leadership & .694 & 1.064 & .171 & 6.232 & $* * *$ & Valid \\
\hline$\times 24$ & Leadership & .588 & .976 & .168 & 5.825 & $* * *$ & Valid \\
\hline $\mathrm{X} 23$ & Leadership & .714 & 1.208 & .184 & 6.550 & $* * *$ & Valid \\
\hline $\mathrm{X} 22$ & Leadership & .704 & 1.119 & .175 & 6.375 & $* * *$ & Valid \\
\hline $\mathrm{X} 21$ & Leadership & .765 & 1.203 & .169 & 7.136 & $* * *$ & Valid \\
\hline X35 & $\begin{array}{l}\text { Organization } \\
\text { Culture }\end{array}$ & .696 & 1.000 & & & & \\
\hline X34 & $\begin{array}{l}\text { Organization } \\
\text { Culture }\end{array}$ & .622 & .840 & .110 & 7.612 & $* * *$ & Valid \\
\hline X33 & $\begin{array}{l}\text { Organization } \\
\text { Culture }\end{array}$ & .682 & 1.137 & .138 & 8.231 & $* * *$ & Valid \\
\hline X32 & $\begin{array}{l}\text { Organization } \\
\text { Culture }\end{array}$ & .734 & .938 & .106 & 8.858 & $* * *$ & Valid \\
\hline X31 & $\begin{array}{l}\text { Organization } \\
\text { Culture }\end{array}$ & .721 & 1.034 & .120 & 8.611 & $* * *$ & Valid \\
\hline Y11 & $\begin{array}{l}\text { Job } \\
\text { Satisfaction }\end{array}$ & .811 & 1.000 & & & & \\
\hline Y12 & $\begin{array}{l}\text { Job } \\
\text { Satisfaction }\end{array}$ & .745 & .918 & .090 & 10.170 & $* * *$ & Valid \\
\hline Y13 & $\begin{array}{l}\text { Job } \\
\text { Satisfaction }\end{array}$ & .806 & 1.051 & .093 & 11.287 & $* * *$ & Valid \\
\hline Y14 & $\begin{array}{l}\text { Job } \\
\text { Satisfaction }\end{array}$ & .800 & 1.075 & .095 & 11.358 & $* * *$ & Valid \\
\hline Y15 & $\begin{array}{l}\text { Job } \\
\text { Satisfaction }\end{array}$ & .806 & 1.029 & .090 & 11.450 & $* * *$ & Valid \\
\hline Y16 & $\begin{array}{l}\text { Job } \\
\text { Satisfaction }\end{array}$ & .796 & .991 & .087 & 11.368 & $* * *$ & Valid \\
\hline Y17 & $\begin{array}{l}\text { Job } \\
\text { Satisfaction }\end{array}$ & .718 & 1.017 & .107 & 9.529 & $* * *$ & Valid \\
\hline Y27 & Performance & .785 & 1.000 & & & & \\
\hline Y26 & Performance & .700 & 1.030 & .111 & 9.243 & $* * *$ & Valid \\
\hline Y25 & Performance & .716 & .996 & .105 & 9.485 & $* * *$ & Valid \\
\hline Y24 & Performance & .740 & .955 & .097 & 9.817 & $* * *$ & Valid \\
\hline Y23 & Performance & .829 & 1.210 & .108 & 11.237 & $* * *$ & Valid \\
\hline Y22 & Performance & .810 & 1.120 & .100 & 11.147 & $* * *$ & Valid \\
\hline Y21 & Performance & .791 & 1.081 & .102 & 10.591 & $* * *$ & Valid \\
\hline
\end{tabular}




\begin{tabular}{|c|c|c|c|c|c|c|c|}
\hline Item & Variables & Reliability & Estimate & S.E. & C.R. & P-Value & Result \\
\hline \multicolumn{8}{|c|}{ Goodness of Fit Model } \\
\hline \multicolumn{2}{|c|}{$\begin{array}{l}\text { Goodness of fit } \\
\text { index }\end{array}$} & \multicolumn{2}{|c|}{ Cut-off Value } & \multicolumn{2}{|c|}{$\begin{array}{l}\text { Result of Modification } \\
\text { Indices }\end{array}$} & \multicolumn{2}{|c|}{ Info } \\
\hline \multicolumn{2}{|c|}{ Chi_Square } & \multicolumn{2}{|c|}{ expected small } & \multicolumn{2}{|c|}{291.813} & \multicolumn{2}{|c|}{ Fit } \\
\hline \multicolumn{2}{|c|}{ Probability } & \multicolumn{2}{|c|}{$\geq 0.05$} & \multicolumn{2}{|c|}{0.099} & \multicolumn{2}{|c|}{ Fit } \\
\hline \multicolumn{2}{|c|}{ CMIN/DF } & \multicolumn{2}{|c|}{$\leq 2.00$} & \multicolumn{2}{|c|}{1.114} & \multicolumn{2}{|c|}{ Fit } \\
\hline \multicolumn{2}{|c|}{ RMSEA } & \multicolumn{2}{|c|}{$\leq 0.08$} & \multicolumn{2}{|c|}{0.029} & \multicolumn{2}{|c|}{ Fit } \\
\hline \multicolumn{2}{|c|}{ GFI } & \multicolumn{2}{|c|}{$\geq 0.90$} & \multicolumn{2}{|c|}{0.868} & \multicolumn{2}{|c|}{ Moderate } \\
\hline \multicolumn{2}{|l|}{ AGFI } & \multicolumn{2}{|c|}{$\geq 0.90$} & \multicolumn{2}{|c|}{0.823} & \multicolumn{2}{|c|}{ Moderate } \\
\hline \multicolumn{2}{|l|}{ TLI } & \multicolumn{2}{|c|}{$\geq 0.94$} & \multicolumn{2}{|c|}{0.975} & \multicolumn{2}{|c|}{ Fit } \\
\hline \multicolumn{2}{|l|}{$\mathrm{CFI}$} & \multicolumn{2}{|c|}{$\geq 0.94$} & \multicolumn{2}{|c|}{0.980} & \multicolumn{2}{|c|}{ Fit } \\
\hline \multicolumn{4}{|c|}{ DF } & \multicolumn{2}{|c|}{262} & & \\
\hline
\end{tabular}

Note: ${ }^{* * *}$ is significant at 0.01 in statistic

Appendix 4: Hypothesis test

\begin{tabular}{|c|c|c|c|c|c|c|}
\hline & Hypothesis & p-value & DE & TE & Info & Results \\
\hline $\mathrm{H} 1$ & $\begin{array}{l}\text { Motivation } \rightarrow \text { Job } \\
\text { Satisfaction }\end{array}$ & 0.016 & 0.267 & 0.267 & $\begin{array}{l}\text { Positive and } \\
\text { Significant }\end{array}$ & Supported \\
\hline $\mathrm{H} 2$ & $\begin{array}{l}\text { Motivation } \rightarrow \\
\text { Performance }\end{array}$ & 0.012 & 0.309 & 0.309 & $\begin{array}{c}\text { Positive and } \\
\text { Significant }\end{array}$ & Supported \\
\hline $\mathrm{H} 3$ & $\begin{array}{l}\text { Leadership } \rightarrow \text { Job } \\
\text { Satisfaction }\end{array}$ & 0.007 & 0.302 & 0.302 & $\begin{array}{c}\text { Positive and } \\
\text { Significant }\end{array}$ & Supported \\
\hline $\mathrm{H} 4$ & $\begin{array}{l}\text { Leadership } \rightarrow \\
\text { Performance }\end{array}$ & 0.000 & 0.869 & 0.869 & $\begin{array}{c}\text { Positive and } \\
\text { Significant }\end{array}$ & Supported \\
\hline $\mathrm{H} 5$ & $\begin{array}{l}\text { Organizational } \\
\text { Culture } \rightarrow \\
\text { Job Satisfaction }\end{array}$ & 0.319 & -0.082 & -0.082 & In-Significant & Not Supported \\
\hline $\mathrm{H} 6$ & $\begin{array}{l}\text { Organizational } \\
\text { Culture } \rightarrow \\
\text { Performance }\end{array}$ & 0.048 & -0.242 & -0.242 & $\begin{array}{c}\text { Negative and } \\
\text { Significant }\end{array}$ & Not Supported \\
\hline $\mathrm{H} 7$ & $\begin{array}{l}\text { Job Satisfaction } \rightarrow \\
\text { Performance }\end{array}$ & 0.026 & 0.273 & 0.273 & $\begin{array}{l}\text { Positive and } \\
\text { Significant }\end{array}$ & Supported \\
\hline
\end{tabular}

